Www.jmscr.igmpublication.org

Impact Factor (SJIF): 6.379

Index Copernicus Value: 79.54

ISSN (e)-2347-176x ISSN (p) 2455-0450

crossrefDOI: https://dx.doi.org/10.18535/jmscr/v7i1.48

Journal Of Medical Science And Clinical Research

IGM Publication

An Official Publication of IGM Publication

\title{
A Clinical Observational Study on Carcinoma Penis in its Clinical Presentation \& Outcome
}

\author{
Authors \\ Sharath Chandran S, Gopikrishna D, Ashwin Muthukumar R \\ Department of General Surgery, Rajah Muthiah Medical College and Hospital, \\ Annamalai University, Annamalai Nagar - 608002, India
}

\begin{abstract}
Background: Carcinoma penis is a rarely occurring carcinoma and management of this condition \& surgical descision of lymph node dissection is vague. In this study various epidemiological, clinical and pathological features were observed and compared with other study \& to study factors which help to decide lymph node dissection and management of this condition.

Materials \& Methods: A prospective study conducted in Division of Urology in Rajah Muthiah Medical College and patients with proven carcinoma penis with biopsy are taken into study and total of 18 patients were observed from July 2016 to June 2018 and all data is compared with global data.

Results: Average age of presentation of disease in this study is found to be around 55 years. Most common presenting complaint is ulceroproliferative growth with associated urinary disturbances with history of recent onset of phimosis in uncircumcised individuals. Site of occurrence of growth commonly involving glans penis. Lesions of size more than $5 \mathrm{cms}$ had strong association with nodal involvement. About $44.40 \%$ of patients had palpable nodes.

Conclusion: High risk group should be identified and screening should be done to find out early diagnosis of pathology ${ }^{(11)(1)}$. Incidence of palpable lymph nodes at time of presentation is higher when compared to western population \& mostly found to be reactive node ${ }^{(9)(14)}$. Personal hygiene measures and personal habits improvement should be educated to patients which can bring down incidence of carcinoma penis.

Keywords: Squmous cell carcinoma, carcinoma penis, Penectomy, Inguinal lymphnode dissection.
\end{abstract}

\section{Introduction}

Carcinoma penis is only $1 \%$ of malignancies in men in developed countries but in developing countries incidence is more and stage of the time of presentation also differs ${ }^{(6)}$. In carcinoma penis single most important predictor of prognosis is lymph node involvement. In case of lymph node involvement ilio-inguinal block dissection can be done and difficulty in regional node management is that more than $50 \%$ of palpable lymph nodes are reactive nodes secondary to infection ${ }^{(13)}$. A small group of clinically negative nodes harbor microscopic metastasis. However ilio-inguinal block dissection cannot be blindly applied to all patients due to risk associated with the procedure. Hence proper selection of patients for regional lymphadenectomy should be done. This study aims at identifying factors which help in decision of lymphadenectomy in case of carcinoma penis. 


\section{Materials \& Methods}

This study is observational prospective study in patients who are biopsy proven as carcinoma penis who got admitted and treated in Division of urology in Rajah Muthiah Medical College between period of July 2016 to June 2018 were included in the study.

At presentation, history is taken \& physical examination carried out and patients are staged and biopsy taken and clinical diagnosis confirmed and assessment of node done. Clinically palpable node were subjected to FNAC and negative node is subjected to course of antibiotics and reassessed after 3 weeks $^{(3)(9)}$. In case of persisting lymph node, excision done and sent for frogen section and decision of lymphadenectomy is decided. Patients with positive inguinal presenting after surgery of primary were treated with lymphadectomy and these people are also included in the study restrospectively.

\section{Results}

A total of 18 patients who are biopsy proven and fulfilling inclusion criteria were included in the study. Treatment option is decided based stage and recommendation of NCCN guidelines.

The summary of results is that, maximum incidence was found in the age group between 4060 years average age of occurrence is around 55 years, which is early compared to western population most common presentation was found to be ulceroproliterative growth $^{(2,10)}$. Most commonly involved site is found to be glans penis. Which was associated with urinary disturbances. Other finding with was noted is recent onset of phimosis which was mostly associated with carcinoma penis.

Average time for seeking medical advice was found to be 9.5 months from the onset of symptoms and $44.42 \%$ of patients had palpable nodes and most of palpable nodes were reactive nodes secondary to infection which responded to course of antibiotic and few clinically negative nodes became palpable after period of time, an average of 10 months which was FNAC proven as positive nodes and treated with lymphadenectomy. Lesions with size greater than $5 \mathrm{~cm}$ and desions with invation of corpora and deeper structures were associated with positive lymph nodes. Histologically moderately and poorly differentiated tumours had more chances of lymph node involvement ${ }^{(16)}$.

\begin{tabular}{|l|c|c|}
\hline Age & No. of Cases & No. of Node $\boldsymbol{~}^{\text {ve }}$ \\
\hline $30-40$ & 1 & 0 \\
\hline $40-50$ & 7 & 4 \\
\hline $50-60$ & 9 & 4 \\
\hline $60-70$ & 1 & 0 \\
\hline Total & 18 & 8 \\
\hline
\end{tabular}

\begin{tabular}{|l|c|c|c|}
\hline Type & Node $\boldsymbol{+}^{\mathbf{v e}}$ & Node $^{\mathbf{v e}}$ & \\
\hline Size $<5 \mathrm{~cm}$ & 2 & 6 & \\
\hline Size $>5 \mathrm{~cm}$ & 6 & 4 & \\
\hline Total & 8 & 10 & 18 \\
\hline
\end{tabular}

\begin{tabular}{|l|c|c|c|}
\hline Type & Node $^{{ }^{\text {ve }}}$ & Node - $^{\text {ve }}$ & \\
\hline Well Diffrentiated & 1 & 7 & \\
\hline $\begin{array}{l}\text { Moderately } \\
\text { Differentiated }\end{array}$ & 1 & 3 & \\
\hline Poorly Differentiated & 6 & 0 & \\
\hline Total & 8 & 10 & 18 \\
\hline
\end{tabular}

\section{Discussion}

Data from the study are collected and compiled and compared with other studies on carcinoma pen's. In our study most common age group was people in $6^{\text {th }}$ decade which is consistent with studies conducted by Guimaraes GC et al. average age of presentation is 55 years. Youngest age of presentation in our study is 32 years which is similar to studies conducted by Gursel et al ulceroproliferative lesion was the most common presentation in our study. Most common site was found to be glans which is similar to studies by suprin get al. most common premalignant lesion associated with it was chronic baloprosthitis ${ }^{(15)}$. Average time of seeking medical advice from onset symptoms is about 9.5 months in our study. Ulcerative \& differentiated tumors have greater incidence of lymphadenopathy. Lesions which was more than $5 \mathrm{~cm}$ in any dimensions has more chance of lymphadenopathy. 


\section{Conclusion}

Carcinoma penis is rarely occurring carcinoma and occurrence of stigmata of seeking medical advice which is present among the people makes early diagnosis of carcinoma penis and premalignant lesions was not possible educating patients about disease and improvement of personal hygiene measures will bring down incidence of carcinoma penis ${ }^{(4)}$. High risk group population should be sorted out and patient should be included in screening programs which will be decrease incidence of disease. Patient with lymphadenopathy, half of the patients have reactive node and can be treated with antibiotics ${ }^{(7)}$. While planning for lymphadenectomy site, single and grade of tumour should be considered for planning lymphadenectomy, clinically palpade lymph nodes alone cannot be considered for lymphadenectomy. Ulcerative lesions, $\mathrm{T}_{3-4}$ stage, moderately and poorly differential tumour with size more than $5 \mathrm{cms}$ are more prone for lymph node metastasis in these case setting lymphadenectomy can be performed ${ }^{(12)}$.

\section{References}

1. Cubilla AL, Milner J, Schellhammer PF, Horenbias S, Ayala AG, Reuter VE, et al. Malignant epithelial tumors of the penis. In: Eble JN, Sauter G, Epstein JI, Sesterhenn IA, editors. Pathology and Genetics of Tumors of the Urinary System and Male Genital Organs. Lyon: IARC Press; 2004:276-90.

2. Jain SP, Agrawal PK, Jain S, Handa K, Sinha N, Dwivedi JN. The frequency of carcinoma of the penis with special reference to North India. Indian J Cancer. 1981;18:250-3.

3. Kaushal V, Sharma SC. Carcinoma of the penis. A 12-year review. ActaOncol. 1987;26:413-7.

4. Prabhakar BR, Gupta S, Prabhakar H. Carcinoma of the penis in Punjab. J Indian Med Assoc. 1976;66:55-7.
5. Reddy CR, Reddy VC, Rao MS. Distribution of malignant tumors in Kurnool. Indian J Cancer. 1967; 4: 64-71.

6. Reddy CR, Raghavaiah NV, Mouli KC. Prevalence of carcinoma of the penis with special reference to India. Int Surg. 1975;60:474-6.

7. Thomas JA, Small CS. Carcinoma of the penis in Southern India. J Urol. 1968; 100:520-6.

8. Cubilla AL, Velazques EF, Reuter VE, Oliva E, Mihm MC, Jr, Young RH. Warty (condylomatous) squamous cell carcinoma of the penis: A report of 11 cases and proposed classification of 'verruciform' penile tumors. Am J SurgPathol. 2000; 24:505-12.

9. Guimarães GC, Cunha IW, Soares FA, Lopes A, Torres J, Chaux A, et al. Penile squamous cell carcinoma clinicopathological features, nodal metastasis and outcome in 333 cases. J Urol. 2009; 182:528-34.

10. Bezerra AL, Lopes A, Landman G, Alencar GN, Torloni H, Villa LL. Clinicopathologic features and human papillomavirus DNA prevalence of warty and squamous cell carcinoma of the penis. Am J SurgPathol. 2001; 25: 673-8.

11. Cubilla AL, Reuter VE, Gregoire L, Ayala $\mathrm{G}$, Ocampos S, Lancaster WD, et al. Basaloid squamous cell carcinoma: A distinctive human papillomavirus-related penile neoplasm: A report of 20 cases. Am J SurgPathol. 1998; 22:755-61.

12. Gregoire L, Cubilla AL, Reuter VE, Haas GP, Lancaster WD. Preferential association of human papillomavirus with high-grade histologic variants of penileinvasive squamous cell carcinoma. J Natl Cancer Inst. 1995; 87:1705-9.

13. Chaux A, Tamboli P, Ayala A, Soares F, Rodríguez I, Barreto J, et al. Wartybasaloid carcinoma: Clinicopathological features a distinctive penile neoplasm. 
Report of 45 cases. Mod Pathol. 2010; 23: 896-904.

14. Chaux A, Lezcano C, Cubilla AL, Tamboli P, Ro J, Ayala A. Comparison of subtypes of penile squamous cell carcinoma from high and low incidence geographical regions. Int J SurgPathol. 2010;18:268-77.

15. Johnson DE, Lo RK, Srigley J, Ayala AG. Verrucous carcinoma of the penis. J Urol. 1985;133:216-8

16. Pettaway CA, Lynch D, Jr, Davis D. Tumors of the Penis. In: Wein AJ, Kavoussi L, Novick AC, et al., eds. Campbell-Walsh Urology (ed 9). Philadelphia: Saunders; 2007:959-992. 